\title{
ANALISIS PEMBENTUKAN UNI MONETER ASEAN-5 DENGAN PENDEKATAN PARITAS INTERNASIONAL DALAM HUBUNGAN KESEIMBANGAN NILAI TUKAR JANGKA PANJANG (1980.01 - 2004.12) *
}

\author{
Siti Aisyah Tri Rahayu ${ }^{1}$ \\ Lukman Hakim ${ }^{1}$ \\ ${ }^{1}$ Fakultas Ekonomi Universitas Sebelas Maret Surakarta \\ E-mail: aisyahrahayu@yahoo.com; lukkim@yahoo.com
}

\begin{abstract}
In order to strengthening cooperation regional and form the strength regional in ASEAN, likely require to relate at successful European Union in forming financial and economic market integration (EMU). ME become the "model" a success economic integration. We can conclude that to reach monetary union have to beforehand realized by economic union supported by union and strong politics willingness, where this matter have been blazed the way old in such a way by leaders of European countries of West which is merged into EMU.

Intention of this research is to see the international parity condition of Purchasing Power Parity (PPP) and rate of interest parity (UIP) of among currency in ASEAN-5 with the currency of United States. Result of this research obtained is show that the goodness of theory of Purchasing Power Parity (PPP) and rate of interest parity (UIP) cannot be holded for the nations of ASEAN-5. In general, hypothesis $\beta \quad 1=1$ refused by existing data. This fact is indication that PPP and UIP cannot be holded during period 1980.01 until 2004.12. With do not hold of two the parity (PPP and UIP) hence possibility to existing of monetary uni ASEAN likely still will passing sufficient process.
\end{abstract}

Keywords: purchasing power parity, rate of interest parity, Monetary Uni ASEAN

\section{PENDAHULUAN}

Dunia bisnis pada awal 1990-an mencatat hubungan bisnis global yang semakin menjalar ke seluruh negara di dunia. Mobilitas

\footnotetext{
Penelitian Dosen Muda dibiayai oleh Direktorat Jenderal Pendidian Tinggi, Departemen Pendidikan Nasional, sesuai dengan dengan Surat Perjanjian Pelaksanaan Penelitian Nomor 033/SPPP/PP-PM/ DP3M/IV/2005 tanggal 11 April 2005. Penelitian ini dilaksanakan pada tahun 2005 dengan Laporan Akhir sebanyak 44 halaman.
}

produksi, modal, dan manusia semakin cepat karena pelaku bisnis semakin menyadari pentingnya pasar global dibanding hanya melayani pasar dalam negeri. Sejalan dengan meningkatnya bisnis yang melewati batasbatas wilayah suatu negara, bank dan lembaga-lembaga keuangan tidak ragu-ragu melayani kebutuhan modal untuk investasi dan operasi ke seluruh dunia. Pasar keuangan disemua negara semakin terkait satu sama 
lain; pergerakan dan perubahan dalam pasar modal satu negara akan membawa dampak langsung terhadap pasar modal di negara yang lain (Kuncoro, 2001:37)

Dunia di abad XXI mengalami berbagai transformasi dalam segala aspek kehidupan manusia, baik sosial, ekonomi, budaya, politik, pertahanan dan sebagainya. Proses transformasi tersebut selaras dengan kekuatan yang mendorong globalisasi, antara lain: (1) globalisasi dari proses industrialisasi, (2) globalisasi keuangan, komunikasi dan informasi, (3) globalisasi kekaryaan, pekerjaan dan migrasi, (4) globalisasi efek polusi biosfir terhadap kehidupan manusia, (5) globalisasi dari perdagangan persenjataan, dan (6) globalisasi kebudayaan, konsumsi, dan media massa (Tilaar, 1997).

Tidak dapat dipungkiri, gelombang globalisasi yang melanda seluruh negara di dunia membuat bisnis internasional menjadi peluang akan semakin menarik. Keadaan semacam ini menghendaki diperlukannya pemahaman akan berbagai metode untuk menembus pasar internasional (Shapiro, 2003:13).

Kondisi kompetisi global dan pasar global untuk barang-barang, jasa-jasa, dan modal adalah kenyataan ekonomi yang mendasar yang perilaku perusahaan dan pemerintahan di seluruh dunia. Meskipun banyak kesempatan untuk dan keuntungan yang bisa diambil dari perekonomian dunia, banyak perusahaan besar dan berpengaruh yang merasa terancam dengan adanya globalisasi dan berjuang mati-matian.

Munculnya batasan-batasan yang menyimpang bagi perusahaan akan mendorong pembuat kebijakan untuk memikirkan ulang pendekatan terhadap regulasi. Sebagai contoh, merger perusahaan yang sebelumnya dilarang karena peraturan anti monopoli, mungkin akan menjadi bermanfaat dan menjadi benar ketika dihadapkan pada kondisi persaingan global dengan pangsa pasar global yang melebihi batasan nasional.

Integrasi perekonomi internasional juga mengurangi kebebasan pemerintah untuk menentukan kebijakan ekonomi mereka sendiri. Jika pemerintah berusaha untuk menaikkan pajak dalam bisnis, sebagai contoh, akan sangat mudah bagi pengusaha untuk memindahkan produksi mereka ke luar negeri. Sama halnya, negara yang gagal menginvestasikan infrastruktur fisik dan intelektual - jalan, jembatan, $\mathrm{R} \& \mathrm{D}$, pendidikan - intelektual dan finansialnya akan berpindah ke tempat yang mereka inginkan dan tinggal di sana. Singkatnya, integrasi ekonomi mendorong negara dan perusahaan untuk berkompetisi (Shapiro, 2003;15)

Dalam konteks globalisasi sosial ekonomi, negara-negara berkembang termasuk Indonesia akan dihadapkan dengan beberapa agenda global maupun regional, antara lain: (1) General Agreement on Tariffs and Trade (GATT), World Trade Organization (WTO), Asia Pasific Economic Cooperation(APEC), dan ASEAN Free Trade Area (AFTA). Dengan demikian bagi kelompok yang optimistik, arus globalisasi dapat disiasati sebagai peluang untuk melakukan lompatan transformatif yang progresif untuk melakukan ekspansi pasar. Sedangkan bagi kelompok yang pesimistis memandang globalisasi sosial ekonomi sebagai ancaman dari bangsa lain, atau predator yang akan memangsa mereka yang lemah (Rustiani, 1996).

Mencermati realita perekonomian Indonesia dalam konteks ekonomi global, 
Sjahrir (2001) mengemukakan bahwa, suasana internal dan eksternal ekonomi Indonesia pada saat ini menunjukkan fenomena yang kurang menggembirakan. Untuk itu Bangsa Indonesia perlu melakukan prioritas dalam memulihkan ekonomi. Jika hal ini tidak segera dilakukan, maka akan menimbulkan berbagai konsekuensi serius, antara lain: (1) semakin meningkatnya harga barang (tingkat inflasi yang tinggi), (2) pengangguran yang semakin membengkak (apalagi pengangguran yang terjadi pada kaum intelektual), (3) kemiskinan struktural yang semakin memilukan, (4) utang yang semakin menggunung baik pada luar negeri maupun dalam negeri, dan (5) pertumbuhan ekonomi yang semakin rendah. Hal ini akan mempengaruhi kondisi sosial politik dan semakin rawannya desintegrasi bangsa, serta potensi konflik atau kerusuhan yang terjadi di tingkat masyarakat lapisan bawah (grassroot) cenderung semakin terbuka.

Berita terakhir mengenai gagalnya perundingan dalam KTM V-WTO telah semakin mendorong negara-negara berkembang untuk semakin meningkatkan kerjasamanya dalam menghadapi tantangan ekonomi global. Bagi negara berkembang kegagalan KTM V merupakan "buying time” untuk konsolidasi posisi nasional. Salah satu konsekuensi dari kegagalan perundingan WTO dalam menegakkan perdagangan multilateral yang fair dan transparan adalah semakin banyak munculnya perdagangan bebas melalui bilateral (free trade area) dan regional, dan bagi negara berkembang yang posisi tawarnya lemah akan semakin terpuruk (Deperindag, 2003).

Indonesia sebagai salah satu negara berkembang dan dalam posisinya sebagai negara yang disegani dalam kerjasama regional di kawasan ASEAN, nampaknya juga sudah sangat perlu untuk bersama-sama dengan negara mitra di kawasan Asia Tenggara meningkatkan kerjasama lebih jauh khususnya di bidang Ekonomi.

Sejak tahun 1992 telah ada kesepakatan antara ASEAN untuk melakukan Kawasan Perdagangan Bebas ASEAN (AFTA). Oleh karenanya, dimulai sejak 1 Januari 1994 sampai 1 Januari 2003 telah dilakukan penurunan tarif bea masuk secara bertahap atas produk-produk negara-negara anggota ASEAN. Pada tahun 2003 sudah 99,07\% atau 7206 pos tarif atas produk-produk Indonesia dengan tarif 0-5\%. Dari jumlah tersebut, sudah $54,65 \%$ yang tarif bea masuknya $0 \%$. Sisanya kurang lebih sebesar $1 \%$ pos tarif, masih dengan tarif bea masuk tinggi karena termasuk dalam kelompok produk-produk sensitif, misalnya otomotif, minuman beralkohol, dan sebagainya.

Meskipun telah dilakukan penurunan tarif bea masuk untuk perdagangan bebas ASEAN, namun total perdagangan intra ASEAN pada tahun 2003 hanya lebih kurang $22,6 \%$ dari total perdagangan ASEAN dengan dunia. Berarti hanya meningkat sebesar 3,3\% bila dibandingkan dengan total perdagangan ASEAN pada tahun 1994 dan $19,3 \%$ dari total perdagangan ASEAN dengan dunia. Para Menteri Ekonomi ASEAN berpendapat bahwa penyebab masih rendahnya total perdagangan intra ASEAN disebabkan karena: (a) sesama anggota ASEAN mempunyai sumber daya yang sama atau menghasilkan produk yang sama, sehingga merasa tidak perlu memperdagangkan dengan sesama ASEAN, dan (b) masih ada hambatan-hambatan non-tarif (Deperindag, 2003). 
Dalam rangka memperkuat kerjasama regional dan membentuk kekuatan regional di ASEAN, nampaknya perlu mengacu pada kesusksesan Uni Eropa dalam membentuk integrasi pasar ekonomi dan finansialnya (EMU). Harus diakui integrasi Eropa Barat dalam ME telah dan akan terus menjadi ajang penelitian yang menarik bagi para peneliti di bidang ekonomi. ME menjadi "model" integrasi ekonomi yang berhasil. Namun dari sini kita bisa menarik kesimpulan juga bahwa untuk mencapai Uni-moneter harus terlebih dahulu diwujudkan economic union yang didukung oleh kesatuan dan kemauan politik yang kuat, dimana hal ini sudah dirintis sedemikian lama oleh para pemimpin negaranegara Eropa Barat yang tergabung dalam EMU.

Keberhasilan EMU dapat menjadi pelajaran yang sangat berharga dan bisa dijadikan acuan dalam membentuk pasar bersatu yang solid di kawasan ASEAN, namun sekaligus bisa menjadi ancaman bagi negara-negara berkembang di ASEAN khususnya, jika negara-negara ASEAN tidak bisa menjadi sparing partner yang seimbang bagi EMU. Tentu saja kondisi semacam ini akan merugikan ASEAN, sehingga terbentuknya integrasi pasar bersama ASEAN nampaknya sudah menjadi hal yang perlu untuk dipertimbangkan lebih lanjut.

Melihat latar belakang di atas, maka ada pertanyaan yang harus segera diselesaikan untuk dicarikan jawabannya, sehubungan dengan terbentuknya integrasi pasar bersama dan uni moneter di kawasan ASEAN. Penelitian ini akan mencoba mencari jawaban dari pertanyaan: Apakah kondisi ekonomi moneter di kawasan ASEAN sudah bisa menjamin dibentuknya uni moneter di Kawasan ASEAN.
Dengan melihat latar belakang masalah di atas dan rumusan permasalahan, maka penelitian ini bertujuan untuk melihat kondisi paritas internasional (Purchasing Power Parity (PPP), Uncovered Interest Parity (UIP) antara mata uang di negara-negara ASEAN dengan mata uang negara Amerika Serikat.

Adapun manfaat penelitian ini diharapkan: a) menjadi bahan pertimbangan bagi kebijakan ekonomi dan perdagangan internasional bagi negara-negara di kawasan ASEAN untuk terbentuknya kerjasama regional yang semakin terintegrasi, b) menjadi bahan pertimbangan bagi pemerintah di negara-negara kawasan ASEAN untuk terbentuknya uni moneter di kawasan negaranegara ASEAN, c) menjadi bahan diskusi ilmiah di bidang ilmu Ekonomi Moneter dan Perdagangan Internasional, khususnya yang terkait dengan pembentukan integrasi pasar bersama ASEAN dan terbentuknya Uni moneter negara-negara ASEAN.

Sejumlah studi awal menemukan kenyataan yang berlawanan dalam paritas jangka pendek (Dornbusch, 1976; Frenkel, 1978). Dalam kenyataannya sudah diterima secara luas bahwa paritas valid dalam jangka panjang, meskipun, penemuan dari literatur berbeda-beda. Sebagai contoh, Ballie dan Selover (1987), Abuaf dan Jorian (1990), dan Kim (1990) menemukan kenyataan yang mendukung hipotesis PPP dalam jangka panjang, sementara Meese dan Singleton (1982) dan Cooper (1994) menolak. Kontroversi teori PPP muncul disebabkan karena proses perolehan data dari variabel yang digunakan berbeda-beda. Dalam studinya, Meese dan Singleton (1982) menemukan bahwa nilai tukar nominal mempunyai akarakar unit. Ini berarti bahwa series mengikuti 
proses random walk dan pergerakannya tidak bisa diprediksi. Dengan kata lain, tingkat hubungan dari series tidak akan dikonfirmasikan baik dalam jangka pendek maupun jangka panjang. Kemudian, uji akar unit seperti Dickey-Fuller test, Augmented Dickey-Fuller (ADF) test, dan Phillip Perron (PP) test dan pendekatan Bayesian unit root diaplikasikan untuk menguji kekuatan teori PPP.

Sebagai contoh, Manzur dan Ariff (1995) menguji keberadaan PPP untuk kelompok tujuh dan Negara-negara ASEAN. Ternyata hipotesisnya ditolak ketika menggunakan Dickey-Fuller, Augmented DickeyFuller, dan PP test. Bagaimanapun, mereka menemukan kenyataan yang mendukung pandangan bahwa nilai tukar tidak mengikuti random walk ketika mereka mengaplikasikan Sim's Test. Sebagai hasilnya, mereka menyimpulkan ada hubungan jangka panjang antara nilai tukar (exchange rate) dan rasio harga dari perekonomian tersebut. Kesimpulan yang sama datang dari Whitt (1992) dengan mengaplikasikan uji yang sama, menggunakan data kuartalan.

Hasil dari kelemahan uji akar unit tradisional, meskipun demikian, lebih banyak lagi para peneliti yang menguji validitas hipotesis dengan mengaplikasikan uji akar unit dengan pendekatan panel dan memberikan hasil yang bermacam-macam. Dengan menggunakan metode Levin dan Lin (1993), Oh (1996), Wu (1996), Papell (1997) dan Lothian (1997) menemukan nilai tukar riil mengikuti proses stasioner selama periode nilai tukar mengambang (float) dalam perekonomian negara-negara OECD.

$\mathrm{Wu}$ (1996) mengestimasi kecepatan penyesuaian dalam 2-3 tahunan menggunakan CPI dan WPI kuartalan, kuartalan dan tahunan. Dengan menggunakan pendekatan Generalized Least Square (GLS), O'Connell (1998) memperlihatkan hubungan antara perekonomian mempunyai dampak yang signifikan dan menolak PPP, sementara Jorian dan Sweney (1996) menemukan bukti yang mendukung stasionaritas nilai tukar riil dengan menggunakan pendekatan yang sama.

Sebagai tambahan, Coakley dan Fuertes (1997) mengadopsi IPS test dan mendukung stasionaritas nilai tukar riil, sementara Canzoneri dkk (1999) menemukan nonstasionaritas nilai tukar riil. Akhir-akhir ini Lothian (1998), Siddique dan Sweeney (1998) dan Koedijk et al (1998) juga mendukung mean reversion dengan menggunakan panel data.

Perkembangan kausalitas dan kointegrasi dikembangkan oleh Engle dan Granger (1987), Johansen (1988), Stock dan Watson (1988), Johansen dan Juselius (1990), Toda dan Yamamoto (1995) meneliti lebih jauh validitas teori PPP dengan menggunakan teknik ekonometri terbaru. Sebagai contoh, Cooper (1994) menggunakan prosedur kointegrasi untuk menguji hubungan jangka panjang antara nilai tukar dan rasio harga untuk tiga perekonomian, Australia, New Klasik Zealand dan Singapura dari 19731992. bagaimanapun, mereka menemukan bukti yang berlawanan dengan validitas teori PPP dalam perekonomian. Huang dan Yang (1996) melaporkan hasil yang sama ketika kointegrasi 2 tahap Engle-Granger diaplikasikan.

MacDonald, Ronald and Ricci, Lucca, (2002) dalam artikelnya, secara teoritis diderivasikan dan secara empiris menguji implikasi dari kerangka teori perdagangan baru untuk perubahan sistematik dalam real exchange rates. Ia memfokuskan pada efek 
dari substitutability dari yang tidak sempurna dari perdagangan dan pada pentingnya kompetisi, dimana dia membangun proxy original. Dengan menggunakan estimasi model dinamik OLS untuk panel dari 9 US dollar real exchange rates, diturunkan koefisien jangka panjang untuk produktivitas relatif dan competitiveness dalam sektor tradable dan non-tradable, yang dikontrol oleh variabel makroekonomi standar. Implikasi dari substitutabilitas yang imperfect dari tradable lebih baik dibanding asumsi neoklasik standar mengenai price equalization. Ukuran competitiveness signifikan secara statistik dalam menerangkan deviasi dari Purchasing Power Parity.

\section{LANDASAN TEORI}

Komponen dari neraca pembayaran memasukkan transaksi komoditi, jasa dan aset. Transaksi-transaksi ini adalah hasil dari keputusan perdagangan barang antar negara, manipulasi dana internasional dengan menggunakan ketidakpastian tingkat bunga, dan ekspektasi dengan spekulasi, sebagaimana mereka juga menghadapi resikonya. Dalam melakukan perdagangan, prinsipprinsip utama dalam perdagangan internasional dan pergerakan modal modal adalah apa yang disebut dengan International Parity Conditions:

- Purchasing Power Parity

$$
\Delta s_{t}^{e}=\Delta p_{t}^{e}-\Delta p_{t}^{e^{*}}
$$

- Interest Rate Parity

$$
f_{t}-s_{t}=r_{t}-r_{t}^{*}
$$

- Unbiased Forward Hypothesis

$$
s_{t+1}^{e}=f_{t} \text {, atau } s_{t+1}^{e}-s_{t}=f_{t-} s_{t}
$$

- Fisher Parity Condition

$$
r_{t}-r_{t}^{*}=\Delta p_{t}^{e}-\Delta p_{t}^{e^{*}}
$$

- International Fisher Parity

$$
s_{t+1}^{e}-s_{t}=r_{t}-r_{t}^{*}
$$

- Real Exchange Rates Interest Rate Parity

$$
\begin{aligned}
\Delta s_{t}^{e}-\left(\Delta p_{t}^{e}-\Delta p_{t}^{e^{*}}=\right. & \left(r_{t}-\Delta p_{t}^{e}\right)- \\
& \left(r_{t}^{*}-\Delta p_{t}^{e^{*}}\right)
\end{aligned}
$$

dimana notasi (kecuali $r_{t}$ dan $r_{t}^{*}$ ) mencerminkan logaritma natural. $s_{t}$ dan $f_{t}$ adalah spot dan forward exchange rates, dinominasikan dengan unit mata uang domestik per unit mata uang asing; $\Delta p_{t}^{e}$ menunjukkan ekspektasi tingkat inflasi; dan $r_{t}$ tingkat suku bunga nominal. Bintang di atas variabel merujuk pada negara asing.

Dalam gambar 1 memperlihatkan bahwa dalam sistem kurs mengambang bebas, kurs spot di masa mendatang secara teoritis ditentukan oleh interaksi antara perbedaan laju inflasi, perbedaan suku bunga dan premi/ diskon forward. Asumsikan kita merupakan penduduk Perancis yang menganggap dollar AS sebagai valas. Bila inflasi di Perancis diharapkan 3\% lebih tinggi dibanding inflasi di AS pada tahun depan, maka nilai franc Perancis diperkirakan akan menurun sekitar 3\% relatif terhadap dollar AS. Pada saat yang sama, suku bunga berjangka satu tahun di Perancis diperkirakan $3 \%$ lebih tinggi dibanding suku bunga berjangka waktu yang sama di AS. 


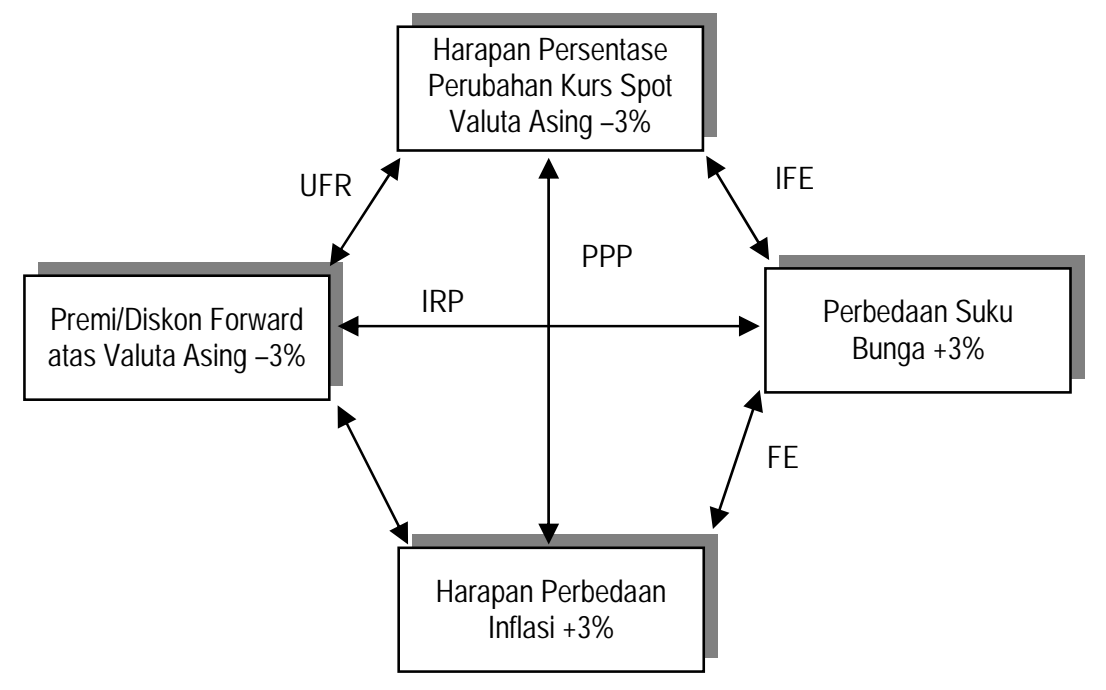

Gambar 1. Lima Hubungan Kunci antara Kurs Spot, Kurs Forward, Inflasi, dan Suku Bunga.

Denominator umum bagi syarat-syarat paritas di atas adalah penyesuaian atas berbagai macam "harga", yaitu: suku bunga (harga mata uang domestik), kurs (harga valas), dan inflasi (indikator tingkat harga umum di suatu negara). Menurut teori moneter modern, inflasi merupakan akibat logis dari ekspansi jumlah uang beredar yang melebihi pertumbuhan output riil, yang pada gilirannya menurunkan daya beli uang. Hubungan antara pertumbuhan jumlah uang yang beredar, inflasi, suku bunga, dan kurs valas dilandasi asumsi bahwa uang adalah netral, artinya perubahan jumlah uang beredar tidak mempunyai dampak terhadap variabel riil (Shapiro, 2003: 118). Dengan demikian, meskipun perubahan jumlah uang beredar akan mempengaruhi harga dan kurs, namun perubahan tersebut tidak mempengaruhi tingkat pertukaran barang-barang di saat ini dan di masa datang. Pendapat semacam ini diformulasikan dalam doktrin Paritas Daya Beli (Purchasing Power Parity) dan Paritas Fisher.

\section{a. Purchasing Power Parity}

Teori Purchasing Power Parity menyatakan bahwa nilai tukar mata uang di antara dua negara sama dengan rasio dari tingkat harga di negara tersebut. Dalam hal ini yang perlu diingat juga adalah bahwa domestic purchasing power parity dari mata uang suatu negara direfleksikan oleh tingkat harga, harga dari sekelompok barang dan jasa. Teori Purchasing Power Parity oleh karenanya memprediksikan bahwa penurunan dalam domestic purchasing power dari mata uang (yang diindikasikan oleh tingkat harga domestik) yang akan berhubungan dengan apresiasi mata uang secara proporsional.

Pemikiran mengenai Purchasing Power Parity ditulis oleh ekonom dari Inggris pada abad 19, di antara mereka adalah David Ricardo (Pengusul teori comparative advantage). Ekonom Swedia, Gustav Cassel menulis di awal abad 20, mempopulerkan Purchasing Power Parity dengan membuat- 
nya menjadi bagian utama dari teori nilai tukar.

Asumsi utama yang mendasari teori PPP adalah bahwa pasar komoditi merupakan pasar yang efisien dilihat dari alokasi, operasional, penentuan harga, dan informasi (Tucker, et al., 1991, h. 45-46). Secara implisit ini berarti: (1) semua barang merupakan barang yang diperdagangkan di pasar internasional tanpa dikenai biaya transportasi; (2) tidak ada hambatan-hambatan dalam perdagangan antarnegara, seperti: tarif, quota, bea masuk, pajak, dan lain-lain; (3) semua barang baik domestik maupun di luar negeri adalah bersifat homogen; (4) adanya kesamaan indeks harga yang digunakan untuk menghitung daya beli mata uang asing dan domestik, terutama tahun dasar yang digunakan dan elemen indeks harganya.

Sehingga jika indeks harga yang digunakandi kedua negara identik, hukum harga tunggal (The Law of One Price) menjustifikasi PPP (Baillie dan McMahon, 1990, hal. 65-66; Eitemen, et.al., 1992, h. 147-8). Artinya, bila produk/jasa yang sama dapat dijual di pasar yang berbeda, tidak ada hambatan dalam penjualan maupun biaya transportasi, maka harga produk/jasa cenderung sama di kedua pasar tersebut. Bila kedua pasar tersebut adalah dua negara yang berbeda, harga produk/jasa tersebut biasanya dinyatakan dalam mata uang yang berbeda, namun harga produk/jasanya tetap masih sama. Perbandingan harga hanya memerlukan suatu konversi satu mata uang ke mata uang lainnya:

$$
P^{R p} \times S=P^{\$}
$$

dimana harga produk dalam Rupiah $\left(P^{R p}\right)$, dikalikan kurs spot ( $S$, Rupiah per dolar AS), sama dengan harga produk tersebut dalam dolar AS $\left(P^{\S}\right)$. Sebaliknya, jika harga kedua produk dinyatakan dalam mata uang lokal, dana pasarnya efisien, maka kurs valas dapat dinyatakan dalam harga lokal relatif produk tersebut:

$$
S=P^{\S} / P^{R p}
$$

dimana $S$ merupakan kurs spot dolar AS per Rupiah.

\section{b. PPP Absolut dan PPP Relatif}

Bila hukum harga tunggal berlaku untuk segala jenis barang dan jasa, kurs PPP dapat dijumpai pada sejumlah harga. Dalam khazanah teori Purchasing Power Parity dikenal dua versi PPP, yaitu: versi absolut dan versi relatif. PPP versi absolut mengatakan bahwa kurs valas dinyatakan dalam nilai harga di dua negara:

$$
S_{t}=P_{t} / P_{t}^{*}
$$

dimana $P_{t}$ dan $P_{t}^{*}$ masing-masing adalah harga rata-rata tertimbang dari komoditi di dua negara (tanda * menunjukkan luar negeri).

Dengan kata lain, PPP absolut menerangkan bahwa kurs spot ditentukan oleh harga relatif dari sejumlah barang yang sama (ditunjukkan oleh indeks harga). Sementara PPP relatif mengatakan persentase perubahan kurs nominal akan sama dengan perbedaan inflasi di antara kedua negara. Dinyatakan dalam konteks mendatang (ex ante terms), harapan perubahan valas sama dengan harapan perbedaan inflasi:

$$
\Delta s_{t}^{e}=\Delta p_{t}^{e}-\Delta p_{t}^{e^{*}}
$$

dimana 
$\Delta s_{t}^{e}=$ harapan perubahan kurs spot,

$$
\left(s_{t+1}^{e}-s_{t}\right) \text {; }
$$

$\Delta p_{t}^{e}=$ harapan perubahan inflasi,

$$
\left(p_{t+1}^{e}-p_{t}\right)
$$

notasi yang dinyatakan dalam huruf kecil berarti dinyatakan dalam bentuk logaritma natural;

tanda * di atas variabel menunjukkan negara asing.

PPP absolut dan PPP relatif dapat dinyatakan dalam nilai kurs Purchasing Power Parity riil (real exchange rates, $\mathrm{S}_{\mathrm{t}}{ }^{\text {PPP }}$ ) sebagai berikut:

$$
S_{t}^{P P P}=S t . P_{t}^{*} / P_{t} .
$$

dimana mendefinisikan kurs riil dalam nilai daya beli antara dua kelompok konsumsi barang. Dengan kata lin, PPP absolut dapat dinyatakan sebagai $S_{t}^{P P P}=1$; dan PPP relatif dapat dinyatakan dalam $S_{t+1}{ }^{P P}=S_{t}^{P P P}$.

\section{c. Paritas Suku Bunga (Interest Parity)}

Doktrin paritas suku bunga mengatakan bahwa perbedaan suku bunga antara dua negara akan sama dengan premi forward dari kurs valas. Jika diformulasikan dalam rumus, sebagai berikut:

$$
f_{t}-s_{t}=r_{t}-r_{t}^{*}
$$

dimana

$\mathrm{ft}=$ kurs forward,

st $=$ kurs spot,

$\mathrm{rt}=$ suku bunga nominal dalam negeri, $\mathrm{rt}^{*}=$ suku bunga nominal luar negeri.

Asumsi yang melandasi paritas suku bunga adalah bahwa pasar aset merupakan pasar yang efisien. Karena itu paritas ini dapat diterapkan untuk investasi dan pinjaman internasional. Logikanya untuk proyek investasi, investor membandingkan hasil (return) dari pasar domestik dengan hasil dari pasar internasional, dimana yang terakhir adalah hasil dari aset luar negeri ditambah premi forward. Bagi proyek pembiayaan, peminjam membandingkan biaya dari pasar domestik dengan pasar luar negeri. Ekuilibrium akan tercapai bila syarat paritas terpenuhi.

\section{d. Hipotesis Kurs Forward yang tidak Bias}

Hipotesis kurs forward yang tidak bias (UFR) menekankan pentingnya menggunakan informasi kurs forward seefektif mungkin untuk memprediksi kurs spot di masa mendatang. Asumsinya, para pelaku ekonomi memiliki harapan yang rasional dan di pasar valas terdapat efisiensi antar waktu. Hipotesis ini mengatakan bahwa harapan pasar terhadap variabel ekonomi fundmental yang mempengaruhi kurs dicerminkan oleh kurs forward. Walaupun kadang-kadang kurs forward dalam memprediksi kurs spot masa mendatang terlalu tinggi atau terlalu rendah, namun rata-rata kurs forward kurang lebih sama dengan kurs spot masa mendatang. Oleh karena itu, kurs forward dipandang sebagai alat prediksi bagi kurs spot masa mendatang atau:

$$
\begin{aligned}
& s_{t+1}^{e}=f t \text { atau } \\
& s_{t+1}^{e}-s_{t}=f t-s_{t}
\end{aligned}
$$

dimana:

$s_{t+1}^{e}$ adalah harapan kurs spot masa mendatang;

$f_{t}$ adalah kurs forward; 
$\mathrm{s}_{\mathrm{t}}$ adalah kurs spot saat ini; huruf kecil berarti dinyatakan dalam logaritma natural.

\section{e. Syarat Paritas Fisher}

Syarat Paritas Fisher, yang dikemukakan oleh Irving Fisher yang menyatakan bahwa suku bunga nominal kira-kira sama dengan suku bunga riil ditambah harapan inflasi. Dengan kata lain, bila persamaan Fisher terbukti benar bagi kedua negara dan suku bunga riil sama di antara kedua negara, maka perbedaan suku bunga nominal akan mencerminkan perbedaan harapan inflasi antara kedua negara, atau dimana $r_{t}$ adalah suku bunga nominal dan $p_{t}^{e}$ adalah harapan inflasi; tanda “*” menunjukkan negara lain; huruf kecil berarti dinyatakan dalam logaritma natural.

\section{f. Paritas Fisher Internasional}

Bila syarat Purchasing Power Parity dimasukkan dalam syarat Paritas Fisher, terlihat bahwa harapan perubahan kurs berhubungan dengan perbedaan suku bunga. Inilah yang disebut Paritas Fisher Internasional, yaitu bahwa kurs spot akan berubah dalam jumlah yang sama namun dengan arah yang berkebalikan dengan perbedaan suku bunga antara dua negara, atau $s_{t+1}^{e}-s_{t}=r_{t}-s_{t}^{*}$

\section{g. Paritas Suku Bunga Riil}

Kadang-kadang, peneliti atau investor peduli tidak hanya pada hubungan nominal tetapi juga hubungan riil antara exchange rate perbedaan tingkat bunga. Sehingga tepat untuk menggambarkan International Fisher Parity Condition dalam batasan riil. Ini dapat dicapai dengan menurunkan tingkat inflasi ekspektasi relatif (atau dengan mengurangi perbedaan natural log dari tingkat harga) dari International Fisher Parity condition. Hasil relasi ini disebut dengan real interest rate parity, yang menyatakan bahwa ekspektasi perubahan dalam real exchange rate sama dengan perbedaan real interest rate.

$$
\begin{aligned}
\Delta s_{t}^{e}-\left(\Delta p_{t}^{e}-\Delta p_{t}^{e^{*}}=\right. & \left(r_{t}-\Delta p_{t}^{e}\right)- \\
& \left(r_{t}^{*}-\Delta p_{t}^{e^{*}}\right)
\end{aligned}
$$

dengan kata lain, perubahan dalam kurs riil diakibatkan oleh perubahan kurs nominal relatif terhadap perubahan dalam harga relatif. Bila Purchasing Power Parity tercapai, yaitu bila $\Delta s_{t}^{e}=\Delta p_{t}-\Delta p_{t}^{*}$, maka kurs riil sama dengan nol. Dengan demikian, perubahan dalam kurs riil pasti disebabkan oleh penyimpangan dalam Purchasing Power Parity.

\section{Kerangka Pemikiran}

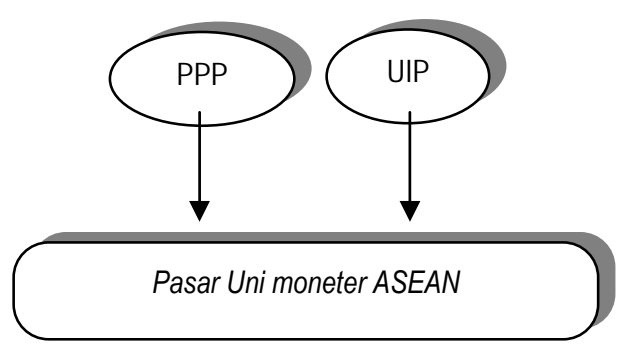

Gambar 2. Kerangka Pemikiran

Dari diagram di atas menunjukkan bahwa ada beberapa komponen yang terbagi dalam beberapa variabel atau faktor-faktor yang mempengaruhi kondisi terjadinya pasar uni moneter ASEAN, seperti) Purchasing Power Parity (PPP), Covered Interest Parity (CIP) dan Uncovered Interest Parity (UIP). Datadata empiris mengenai variabel-variabel penentu berlakunya uni moneter ASEAN 
yang akan diamati dalam penelitian ini adalah selama masa tahun 1980.01-2004.

\section{Hipotesis}

Pendekatan Paritas Internasional memilki asumsi bahwa harga barang dapat bergerak secara leluasa (perfectly flexible) akibat tidak adanya pajak dan biaya transportasi serta diasumsikan bahwa semua barang dalam pasar merupakan traded goods. Kedua asumsi ini menghendaki kondisi pasar berada dalam keadaan persaingan sempurna. Implikasinya, bahwa suatu negara dapat membeli barang di suatu negara yang memiliki harga paling murah.

Pada kondisi normal, kurs yang tercipta biasanya cenderung mengikuti paritas daya belinya. Dalam jangka pendek, destabilizing speculation memiliki kekuatan untuk mempengaruhi fluktuasi kurs hingga kurs yang terjadi cenderung meninggalkan paritas daya belinya. Apabila kekuatan destabilizing speculation menurun, maka kurs riil akan kembali mendekati paritas daya beli. Penyimpangan kurs dapat terjadi karena adanya penilaian yang berlebihan terhadap mata uang asing, yang biasanya dipicu oleh tingginya inflasi di dalam negeri. Tingginya inflasi dapat melemahkan dan menurunkan daya saing ekspor terhadap barang-barang impor.

Selain faktor di atas, peranan intervensi pemerintah juga diyakini turut bermain dalam menciptakan berapa besarnya nilai kurs ideal. Apabila ditelusuri lebih lanjut, kestabilan kurs yang diciptakan melalui intervensi, dan bukan melalui mekanisme pasar, sebenarnya tidak akan bertahan lama. Hal ini disebabkan karena cadangan devisa yang dipakai untuk menjaga kestabilan kurs apabila terjadi penyimpangan, pasti semakin lama semakin menipis. Kondisi ini secara tidak langsung akan mengakibatkan pergerakan kurs menjadi semakin tidak terkendali.

Negara-negara ASEAN merupakan negara yang memiliki proteksi tinggi terhadap industri dalam negeri. Apabila dalam suatu perdagangan terdapat berbagai macam barriers, baik tarif maupun non tarif, maka dapat mengakibatkan traded goods menjadi nontraded goods. Semakin banyak barriers yang diterapkan dalam perdagangan, maka perdagangan yang terjadi sifatnya makin tidak sempurna dan paritas daya beli dan paritas internasional lainnya menjadi tidak berlaku. Adanya pengaruh biaya transaksi, biaya transportasi, tarif maupun proteksi lainnya, diyakini akan membuat keseimbangan paritas daya beli dan paritas internasional menjadi terganggu, begitu pula apabila terdapat distorsi harga perdagangan itu sendiri.

Berangkat dari asumsi-asumsi tersebut di atas, maka hipotesis yang bisa dikemukakan dalam penelitian ini adalah:

Konsep keseimbangan Paritas Internasional (Purchasing Power Parity, Uncovered Interest Parity) berlaku dalam jangka panjang antara negara-negara ASEAN dan negara Amerika Serikat.

\section{METODE PENELITIAN}

\section{Skope Penelitian}

Penelitian mengenai Analisis Pembentukan uni moneter ASEAN ini mengambil sampel lokasi di lima negara yang tergabung di ASEAN yaitu Indonesia, Malaysia, Singapura, Philipina, dan Thailand. 


\section{Jenis Data, Sumber, dan Pengumpulannya}

Data yang digunakan dalam penelitian ini adalah data bulanan yang diperoleh dari International Financial Statistics (IFS), dengan periode pengamatan 1980.012004.12. Data nilai tukar adalah data nilai tukar pada periode akhir bulanan (nilai tukar dinyatakan dalam mata uang domestik terhadap US Dollar), dinyatakan dalam satuan Rupiah, Ringgit, Dollar Singapura, Peso dan Baht. Data harga yang digunakan adalah Consumer Price Index (CPI) dengan tahun dasar 1990.

\section{Operasional Variabel}

$s_{t}=$ kurs mata uang domestik yang dihitung dalam mata uang asing, dalam hal ini terhadap dollar. Variabel ini diukur dalam nilai logaritma natural.

$r_{t}=$ suku bunga nominal, yang diukur dengan suku bunga deposito 1 bulanan. Variabel ini diukur dalam nilai prosentase.

$\pi_{t}=$ tingkat inflasi, yang diukur dengan perubahan Indeks Harga Konsumen dengan tahun dasar 1990. Variabel ini diukur dalam nilai logaritma natural.

\section{Teknik Analisis Data}

Untuk menguji hipotesis pertama dan kedua akan dicoba mengaplikasikan model dari persamaan-persamaan dalam Paritas Internasional. Sehingga spesifikasi model yang dipakai adalah sebagai berikut:

- Purchasing Power Parity

$$
\Delta s_{t}^{e}=\Delta p_{t}^{e}-\Delta p_{t}^{e^{*}}
$$

- Interest Rate Parity

$$
f_{t}-s_{t}=r_{t}-r_{t}^{*}
$$

dimana notasi (kecuali $r_{t}$ dan $r_{t}^{*}$ ) mencerminkan logaritma natural. $s_{t}$ dan dan $s_{t+1}$ adalah spot dan forward exchange rates, dinominasikan dengan unit mata uang domestik per unit mata uang asing; $\Delta p_{t}^{e}$ menunjukkan ekspektasi tingkat inflasi; dan $r_{t}$ tingkat suku bunga nominal. Bintang di atas variabel merujuk pada negara asing.

Metode estimasi regresi yang digunakan untuk melihat dipegang atau tidaknya kondisi Paritas Internasional antara negara-negara di kawasan ASEAN dengan Amerika Serikat digunakan metode regresi dengan Panel Data gabungan dari data time series dan cross section atau pooling regression.

Ada banyak cara untuk menaksir model dalam ekonometri. Dalam studi ini salah satu teknik yang akan dipakai adalah teknik penaksiran Generalized Least Square (GLS) yang biasa digunakan untuk menganalisis panel data time series dan cross section. Dalam studi ini penaksiran tidak dilakukan dengan teknik Ordinary Least Squre (OLS) biasa, sebab data yang digunakan adalah pooled data atau panel data, dimana ada analisis yang membedakan antar unit individu dan antar waktu yang harus diperhitungkan.

Ada beberapa alasan mengapa anlisis yang dipakai adalah analisis panel data, yaitu (Gujarati, 1995: 524):

1. Dengan $O L S$ biasa, apabila dilakukan terpisah, diasumsikan bahwa parameter regresi tidak berubah antar waktu (temporal stability) dan tidak berbeda antar unit-unit individunya (crosssectional unit).

2. Dengan $O L S$ biasa, akan terjadi asumsi yang sangat sempit tentang asumsi klasik; homoscedasticity dan autocorre- 
lation (pasti homoskedastis dan tidak berkorelasi pada variabel kesalahan)

Menurut Hsiao (Hsiao,1990:1-2), penggunaan panel data dalam penelitian ekonomi mempunyai beberapa keunggulan dibandingkan dengan data time series atau data cross section biasa. Pertama, ia biasanya memberi kepada peneliti sejumlah data yang banyak, menaikkan derajad kebebasan (degrees of freedom) dan mengurangi kolinearitas (hubungan) di antara variabel penjelas (explanatory variables) - oleh karena itu akan menghasilkan estimasi ekonometrik yang efisien. Kedua, yang lebih penting lagi adalah data longitudinal membolehkan peneliti untuk menganlisis sejumlah pertanyaan penting yang tidak dapat dipecahkan hanya dengan menggunakan data cross sectional atau data time series.

Secara umum, model regresi mempunyai bentuk sebagai berikut:

$$
y_{i t}=\alpha_{i}+\beta^{\prime} x_{i t}+\varepsilon_{i t}
$$

dimana $i=1,2, \ldots . N$ merujuk pada unit cross section, dan $t=1,2, \ldots T$ merujuk pada satu waktu tertentu. $y_{i t}$ merupakan nilai dari dependent variable dari individu $i$ pada waktu $t$ dan $x_{i t}$ adalah nilai dari nonstochastic explanatory variable untuk individu $i$ pada waktu $t$. Ada sejumlah $K$ regressor pada $x_{i t}$, tidak termasuk constant term. $\alpha$ i adalah individual effect yang konstan antar waktu $t$ dan spesifik untuk masing unitunit cross section $i$. Seperti diketahui bahwa model ini disebut dengan model regresi klasik. Jika kita menganggap $\alpha_{i}$ adalah sama untuk semua unit individu, maka OLS memberikan estimasi yang koefisien untuk parameter $\alpha_{i}$ dan $\beta$. Ada dua pendekatan mendasar yang digunakan dalam menganali- sis Panel Data, yaitu: Pertama, disebut dengan pendekatan Fixed Effect yang menetapkan bahwa $\alpha_{\mathrm{i}}$ adalah sebagai kelompok yang spesifik atau berbeda dalam constant term dalam model regresinya. Kedua, pendekatan Random Effect, meletakkan $\alpha_{\mathrm{i}}$ adalah gangguan spesifik kelompok, sama dengan $\varepsilon_{i t}$, kecuali untuk masing-masing kelompok, tetapi gambaran tunggal yang memasukkan regresi sama untuk tiap-tiap periode.

\section{ANALISIS HASIL ESTIMASI}

Sesuai dengan studi yang telah dikemukan pada awal tulisan ini, yakni menganalisis pembentukan uni pasar ASEAN dengan menggunakan pendekatan keuangan internasional. Di sini pertimbangan pembentukannya didasarkan atas diterimanya asumsi (hold) purchasing power parity (PPP) dan Uncovered Interest rate parity yang akan diuraikan sebagai berikut:

\section{Purchasing Power Parity (PPP) ASEAN}

Dari hasil pengolahan data terlihat bahwa dari sudut uji parsial atau uji tes terlihat bahwa hubungan variabel dengan metode data polling signifikan. Demikian juga dilihat dari sudut goodness of fit atau $\mathrm{R}^{2}$ juga terlihat bahwa hasil model adalah sangat bagus yakni mencapai nilai 0,98 atau dengan kata lain variasi variabel independen dapat menjelaskan variabel dependennya sebesar $98 \%$. 
Tabel 1. Hasil Pengolahan Panel Data Purchasing Power Parity Negara ASEAN-5 (1980.012004.12)

\begin{tabular}{lc}
\hline Variabel Independen & Konstanta \\
\hline Konstanta & \\
- Indonesia & 2.910495 \\
- Malaysia & 0.446201 \\
- Singapura & 0.253708 \\
- Tahiland & 1.452135 \\
- Philipina & 1.380994 \\
Harga (P) & 0.004056 \\
& $(44,58)^{\star \star \star}$ \\
\hline $\mathrm{R}^{2}$ & 0,98 \\
$\mathrm{~N}$ & 300 \\
\hline
\end{tabular}

Keterangan:angka dalam kurung menunjukkan uji t-statistik

Dari sudut tanda koefisien yang dihasilkan sesuai dengan teori yakni positif. Artinya hubungan antara harga dengan nilai tukar di ASEAN adalah searah. Atau jika harga naik, maka nilai tukar juga akan meningkat. Namun dari sisi besaran nilai koefisiennya sangat kecil sekali yakni hanya sektiar 0,004, ini menandakan pola hubungan yang relatif lemah, kendatipun sesuai dengan teori.

Tabel 2. Uji Wald untuk Model Panel Data Purchasing Power Parity Negara ASEAN-5 (1980.01-2004.12)

Hipotesis nol: $\mathrm{C}(1)=1$

\begin{tabular}{llll}
\hline F-statistik & 120000000 & Probabilitas & 0.0000000 \\
Chi-square & 120000000 & Probabilitas & 0.0000000
\end{tabular}

\section{Uncovered Interest Rate Parity (UIP) ASEAN}

Sementara itu, hasil pengujian UIP sangat jauh berbeda hasilnya dengan PPP. Dari hasil pengolahan data terlihat bahwa dari sudut uji parsial atau uji tes terlihat bahwa hubungan variabel dengan metode data polling tidak signifikan. Demikian juga dilihat dari sudut goodness of fit atau $\mathrm{R}^{2}$ juga terlihat bahwa hasil model ini tidaklah bagus karena nilainya $0,00014 \%$ atau dengan kata lain variasi variabel independen dapat menjelaskan variabel dependennya kurang dari $1 \%$.

Demikian halnya jika dilihat dari sudut tanda koefisien yang dihasilkan tidak sesuai dengan teori. Jika secara teoritis seharusnya bertanda positif, maka hasil dari pengolahan data adalah negatif. Artinya hubungan antara harga dengan nilai tukar di ASEAN adalah tidak searah. Atau jika harga naik, maka nilai tukar juga akan menurun, dan besaran nilai koefisiennya sangat kecil sekali yakni hanya sekitar 0,00008 , ini menandakan pola hubungan yang relatif lemah, dapat dilihat pada tabel 3 .

Tabel 3. Hasil Pengolahan Panel Data Uncovered Interet Parity Negara ASEAN-5 (1980.01-2004.12)

\begin{tabular}{lc}
\hline Variabel Independen & Konstanta \\
\hline Konstanta & \\
- Indonesia & 0.001319 \\
- Malaysia & 0.000464 \\
- Singapura & 0.000268 \\
- Tahiland & 0.000718 \\
- Philipina & 0.000955 \\
& \\
\hline Harga (P) & 0.0000884 \\
& $(-0.455517)$ \\
\hline $\mathrm{R}^{2}$ & 0,000139 \\
$\mathrm{~N}$ & 299 \\
\hline
\end{tabular}

Untuk melihat apakah hasil ini sesuai dengan tujuan dari studi atau terjadi "hold", maka perlu dilakukan uji Wald. Dari hasil uji Wald ternyata menolak hipotesis "hold". Maka, dengan tertolaknya asumi itu, rencana untuk membentuk uni pasar ASEAN tidak memenuhi syarat dari sudut UIP. Hasil ini 
sama dengan tinjauan dari sudut PPP, dapat dilihat pada tabel 4 .

\section{Tabel 4. Uji Wald untuk Model Panel Data Un- covered Interet Parity Negara ASEAN- 5 (1980.01-2004.12)}

\begin{tabular}{llll}
\hline \multicolumn{2}{l}{ Hipotesis nol: $C(1)=1$} & & \\
\hline F-statistik & 26553502 & Probabilitas & 0.0000000 \\
Chi-square & 26553502 & Probabilitas & 0.0000000 \\
\hline
\end{tabular}

\section{KESIMPULAN}

Penelitian ini bertujuan untuk menguji hipotesis bahwa Paritas Internasional yang terdiri dari Paritas Daya Beli (PPP) dan Paritas Suku Bunga (UIP) berlaku dalam keseimbangan jangka panjang, dengan menggunakan data panel negara ASEAN-5 (Indonesia, Malaysia, Singapura, Philipina dan Thailand). Pengujian dilakukan dengan menggunakan basis Dollar Amerika untuk negara-negara ASEAN-5. Hasil penelitian memperlihatkan kenyataan sebagai berikut:

a. Hasil estimasi menunjukkan teori Purchasing Power Parity tidak bisa dipegang (tidak "hold") untuk negaranegara ASEAN-5. Secara umum, hipotesis $\beta_{1}=1$ ditolak oleh data yang ada. Kenyataan ini mengindikasikan bahwa Purchasing Power Parity tidak bisa dipegang selama periode 1980.2 sampai 2004.12.

b. Sementara itu hasil estimasi Uncovered Interest Parity juga menunjukkan hal yang sama dengan hasil estimasi PPP, yakni tidak "hold", selama periode pengamatan.

c. Dengan tidak terpegangnya dua paritas tersebut (PPP dan UIP) maka kemungki- nan untuk terwujudnya uni moneter ASEAN nampaknya masih akan melalui proses yang cukup lama. Pada saat ada kemungkinan bahwa kondisi Purchasing Power Parity tidak dapat berlaku dalam jangka panjang, maka bukan berarti bahwa teori tentang Purchasing Power Parity tidak dapat dijalankan. Hasil ini lebih disebabkan karena adanya faktorfaktor yang menyebabkan asumsi dari Purchasing Power Parity tidak terpenuhi dengan baik. Adanya perbedaan dalam struktur proteksi dimasing-masing negara, adanya kemungkinan indeks harga memiliki struktur penimbang yang berbeda serta adanya struktur data yang berbeda, bisa menyebabkan asumsi Paritas Daya Beli (Purchasing Power Parity) dan Interest Parity menjadi tidak berlaku.

Pengujian Paritas Daya Beli dan Paritas Suku Bunga membawa implikasi penting khususnya terhadap upaya integrasi modal, yang mau tidak mau, tergantung pula terhadap bekerjanya Paritas Internasional. Secara teoritis, apabila Paritas Daya Beli berjalan, maka modal yang masuk dari luar negeri akan diikuti oleh fluktuasi dalam kurs sehingga mengakibatkan bekerjanya pula paritas tingkat bunga. Masuknya modal asing kemudian akan dicerminkan melalui perubahan kurs. Sebaliknya, apabila Paritas Daya Beli tidak berjalan, maka Paritas Suku Bunga pun juga ikut tidak berjalan.

Berbagai macam hambatan perdagangan yang saat ini masih banyak diberlakukan di negara-negara ASEAN-5 melalui tarif dan non tarif merupakan satu masalah yang menghambat dalam perdagangan internasional. Kondisi paritas juga akan sulit berjalan apabila barang-barang domestik sulit 
bersaing dan tetap menjadi non-traded goods. Sehingga diharapkan upaya integrasi modal akan lebih mudah dicapai apabila tingkat proteksi diturunkan.

Selain faktor di atas, juga faktor resiko yang terkait dengan ketidakpastian pelaku pasar dalam melihat country risk, terutama dipicu oleh ketidakstabilan kondisi sosial politik yang berperan cukup besar (terutama untuk negara Indonesia). Di samping faktor intervensi pemerintah dalam hal ini otoritas moneter merupakan faktor penting yang perlu mendapat perhatian untuk dimasukkan ke dalam model, tetapi ternyata tidak bisa karena keterbatasan dalam memperoleh data yang diinginkan.

\section{DAFTAR PUSTAKA}

Alan M. Taylor, 2000, “A Century of Purchasing Power Parity", NBER Working Paper No. 8012, November.

Alan M. Taylor, 2000, "Potential Pitfalls for the Purchasing-Power-Parity Puzzle? Sampling and Specification Biases in Mean-Reversion Tests of the Law of One Price", NBER Working Paper Series Working Paper 7577, March.

Balassa, Bela, 1964, "The Purchasing Power Parity Doctrine: A Reappraisal", The Journal of Political Economy, vol 72, no. 6.

Basri, Muhammad Chatib, 1997, "Purchasing Power Parity dalam Jangka Panjang: Studi Kasus Indonesia dan Australia", Bisnis dan Ekonomi Politik, vol. I (1).

Batiz, Francisco L. Rivera and Luis A. Rivera Batiz, 1994, International Finance and Open Economy Macroecono- mics, New York: Macmillan Publishing Company.

Charles Engel and James C. Morley, 2001, "The Adjustment of Prices and the Adjustment of the Exchange Rate", NBER Working Paper Series No. 8550, October.

David C. Parsley and Shang-Jin Wei, 2003, "A Prism into the PPP Puzzles: The Micro-foundations of Big Mac Real Exchange Rates", NBER Working Paper Series Working Paper 7577, August.

Depperindag, 2003, Bahan Sosialisasi Kerjasama ASEAN plus Free Trade Area, Yogyakarta 15 Desember 2003, makalah, tidak dipublikasikan.

Engle, R.F. dan B.S. Yoo, 1987, "Forecasting and Testing in Cointegrated System", Journal of Econometrics, 1987, 35, hal. 143-159.

Engle, R.F. dan C.W.J. Granger, 1987, “Cointegration and Error Correction and Representation, Estimation and Testing”, Econometrica, 1987, 55, hal. 251276.

Greene William H., 2000, Econometric Analysis, Fourth Edition, New Jersey: McGraw-Hill, Inc.

Gujarati, D.N., 1995, Basic Econometrics, New Jersey: McGraw-Hill, Inc.

Hsiao, Cheng, 1995, "Analysis of Panel Data", Econometrics Society Monographs No. 11, USA: Cambridge University Press.

Insukindro, 1990, "Pendekatan Stok Penyangga Permintaan Uang: Tinjauan Teoritik dan Sebuah Studi Empirik di Indonesia", Jurnal Ekonomi dan 
Keuangan Indonesia, FE UI Vol. 46, No. 4: 451-471.

Insukindro, 1990, ”The Monetary Sector in Indonesia: Time Series Property of the Data and Some Issues of Model Spesification", Ekonomi dan Keuangan Indonesia, Vol. 38, No.2

Insukindro, 1990a, "Pendekatan Empirik \& Kointegrasi”, Jurnal Ekonomi dan Keuangan Indonesia, Vol. 46 No. 4: 451-471

Insukindro, 1992b, "Dynamic Specification of demand for Money a Survey of Recent Development", Jurnal Ekonomi Indonesia, Vol. 1, No. 1: 9-23

Insukindro, 1992c, ”Pendekatan Kointegrasi dalam Analisis Ekonomi: Studi Kasus Permintaan Deposito dalam Valuta Asing di Indonesia", Jurnal Ekonomi Indonesia, Vol. 1, No. 2: 259-270

Insukindro, 1993, "Ekonomi Uang dan Bank: Teori dan Pengalaman di Indonesia", Yogyakarta: BPFE-UGM.

Insukindro, 1999, "Pembentukan Model dalam Penelitian Ekonomi", Jurnal Ekonomi dan Bisnis Indonesia, Tahun VII, No. 1: 1-8.

Insukindro, 1999, "Pemilihan Model Ekonomi Empirik dengan Pendekatan Koreksi Kesalahan", Jurnal Ekonomi dan Bisnis Indonesia, Vol. 14, No. 1: 1-8.

Jack H. Penm, Jammie Penm and R.D Terrel, 2005, "Testing Purchasing Power Parity in the Framework of Vector Error Correction Modelling", The Australian National University.

Jack H. Penm, Jammie Penm and R.D Terrel, 2006, "Testing Purchasing Power Parity and Efficiency in the Taiwan Foreign
Exchange Rates", the Australian National University.

John T. Cuddington and Hong Liang, 1998, "Re-Examining the Purchasing Power Parity Hypothesis over Two Centuries", Journal of International Money and Finance (2000).

Krugman, Paul R. dan Maurice Obstfeld, 1997, International Economics: Theory and Policy, $4^{\text {th }}$ Edition, Addison Wesley Longman Inc.

Leonardo Fernando Cruz Basso, 1998, “An Alternative Theory for Exchange Rate Determination" Social Science Research Network Electronic Paper Collection, April 1998.

Levich, Richard M., 1996, "Empirical Studies of Exchange Rates: Price Behavior, Rate Determination, and Market Efficiency" dalam Ronald W. Jones dan Peter B. Kenen, Handbook of International Economics: International Monetary Economics and Finance, edisi II, North Holland

MacDonald, Ronald dan Mark P. Taylor, 1993, "Exchange Rate Economics: A Survey”, IMF Staff Papers, vol 49, no. 1.

MacDonald, Ronald dan Mark P. Taylor, 1993, "The Monetary Approach to the Exchange Rate", IMF Staff Papers, vol 40, no. 1.

Maddala, G.S., 1998, Introduction to Econometrics, MacMillan Publishing Company.

Mankiw, Gregory N., 1994, Macroeconomics, Second Edition, New York: Worth Publisher. 
Meese, Richard A. and Kenneth Rogoff, 1983, "Empirical Exchange Rate Models of the Seventies: Do They Fit Out of Sample?" Journal of International Economics, no. 14.

Mudrajad Kuncoro, 2001, Manajemen Keuangan Internasional, Edisi Kedua, Yogyakarta: BPFE UGM.

Musa, Michael L., 1976, “The Exchange Rate, the Balance of Payments and Monetary and Fiscal Policy under a Regime of Controlled Floating", Scandinavian Journal of Economics, vol. 78, no. 2 .

Parkin, Michael dan Robin Bade, 1982, Modern Macroeconomics, Oxford: Philip Allan Published Limited.

Philippe Bacchetta and Eric van Wincoop, 2002, "A Theory of the Currency Denomination of International Trade", NBER Working Paper Series No. 9039, July 2002.

Reksoprajitno, Soedijono, 1989, Ekonomi Internasional, Yogyakarta: Penerbit Liberty.

Rustiani, F. F. (Ed), 1996. Prosiding Dialog Nasional dan Lokakarya Pengembangan Ekonomi Rakyat dalam Era Globalisasi: Masalah, Peluang dan Strategi Praktis. Yayasan Akatiga dan Yapika.

Salvatore, Dominick, 1995, International Economics, $5^{\text {th }}$ Edition, MacMillan

Sebastian Edwards and Miguel A. Savastano, 2003, "Exchange Rates in Emerging Economies: What Do We Know? What do We Need to Know?", NBER Working Paper 7228.
Shapiro, Alan C., 2003, Multinational Financial Management, $7^{\text {th }}$ edition, Wiley \& Sons

Simón Sosvilla-Rivero and Emma García, 2003, "Forecasting the Dollar/Euro Exchange Rate: Are International Parities Useful?" Documento De Trabajo 200315

Sjahrir, 2001. Kompas Tanggal 29 Oktober Halaman 15.

Soesastro, Hadi dan Muhammad Chatib Basri, 1998,"Survey of Recent Developments", Bulletin of Indonesian Economics Studies, vol 34, no.1

The World Bank, 1997, "The State in Changing World', World Development Report 1997.

Thomas, R.L., 1993, Introductory Econometrics: Theory and Applications, Longman Group UK Limited.

Thomas, RL, 1997, Modern Econometrics: An Introduction, Addison Wesley Limited.

Tilaar, H.A.R, 1997. Pengembangan Sumberdaya Manusia dalam Era Globalisasi. Jakarta: Gramedia Widiasara Indonesia.

Tucker Alan L., Jeff Madura and Thomas C. Chiang, 1998, International Financial Markets, USA: West Publishing Company.

Yin-Wong Cheung, Menzie D. Chinn dan Eiji Fujii, 2003, "China, Hong Kong, and Taiwan: A Quantitative Assessment of Real and Financial Integration",Cesifo Working Paper No. 851, Category 6: Monetary Policy and International Finance, January 2003 
Yin-Wong Cheung, Menzie D. Chinn, Antonio Garcia Pascual, 2002, "Empirical Exchange Rate Models of the
Nineties: Are any Fit to Survive?" NBER Working Paper 9393, December 2002. 